\title{
Surgical Treatment of Late Presented Displaced Lateral Condylar Fracture of the Humerus in Children
}

\author{
Ki Cheor Bae, M.D., Kwang Soon Song, M.D., Chul Hyung Kang, M.D., \\ Byung Woo Min, M.D., Chul Hyun Cho, M.D., and Hyub Sa-Kong, M.D. \\ Department of Orthopedic Surgery, School of Medicine, Keimyung University, Daegu, Korea
}

\section{지연 발현된 전위된 소아 상왼골 외과 골절의 수술적 치료}

\author{
배기철· 송광순 · 강철형 · 민병우 · 조철현 · 사공협 \\ 계명대학교 의과대학 동산의료원 정형외과학교실
}

\begin{abstract}
Purpose: To determine whether late open reduction and internal fixation (ORIF) of a lateral condylar fracture (LCF) after 3 weeks is possible, and to determine the latest time for ORIF without a bone graft. Materials and Methods: Eight children underwent late ORIF ( $>3$ weeks) of a displaced LCF $(>2.5 \mathrm{~mm})$ of the humerus between 3 weeks and 5 weeks after injury.

Results: Clinically, results were excellent in 6 cases and good in 2 cases. There was no serious complication, including nonunion and avascular necrosis (AVN), though 2 cases had a slight fishtail deformity and mild carrying angle loss due to overgrowth of the lateral condyle fragment.

Conclusion: We believe that 3 weeks is too short to deny open reduction and anatomic reduction for fear of AVN of a late presented lateral condyle fracture of the humerus. The latest time for ORIF in late presented LCF in children is around 5 weeks, and surgical treatment may even be possible after greater delays.
\end{abstract}

Key Words: Lateral condyle fracture of the humerus, Late open reduction, Children

\section{INTRODUCTION}

An adequate treatment of fractures of the lateral condyle fracture (LCF) in children may be delayed due to a failure to recognize the fracture initially or subsequent displacement of unstable minimally displaced fragment during simple cast immobilization. Moreover, nonunion may develop and not be recognized by an orthopedist during the treatment of a minimally displaced LCF of the humerus, and sometimes nonunion is not discovered until deformity and pain have developed ${ }^{5-8)}$. If displacement occurs, an operative procedure involving some type of firm fixation is indicated when seen early ${ }^{2,6-9)}$. However, the management of these fractures when presented late is controversial $^{3,4,9-13,17,18)}$. Several studies have found that patients treated within 2 or 3 weeks by open reduction and internal fixation (ORIF) did well, but

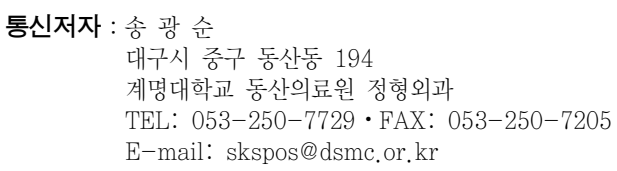

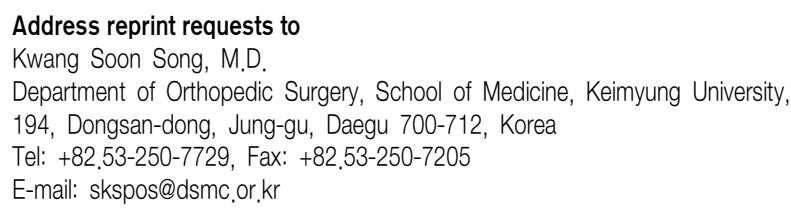

*The present research has been conducted by the Bisa Research Grant of Keimyung University in 2006. 
that open reduction at more than 3 weeks after fracture offered no benefit versus no treatment at $\mathrm{all}^{4,9,13)}$ However,

Wattenbarger et al reported good results by open reduction in late presenting children with no avascular necrosis (AVN) of the capitellum $(>3$ weeks) ${ }^{15)}$. However, most reports do not mention a maximum delay for ORIF in LCF. The main purpose of this study was to determine whether late ORIF after 3 weeks results in poor results, and the secondary purpose was to determine the latest time for ORIF without bone graft in LCF.

\section{MATERIALS AND METHODS}

From August 1998 to July 2002, eight children, who had been referred, underwent late ORIF ( $>3$ weeks; from 3 to 5 weeks after injury) for a displaced LCF $(>2.5 \mathrm{~mm})$ of the humerus. We reviewed all medical records. Three orthopedic surgeons (all with more than 7 years experience) measured displacement of the lateral condyle fragment at presentation, immediate after late ORIF, and at final follow ups. Displacements were measured from the metaphyseal lateral cortex of the distal humerus to the lateral cortex of the fragment on anterior posterior radiographs. Pos-
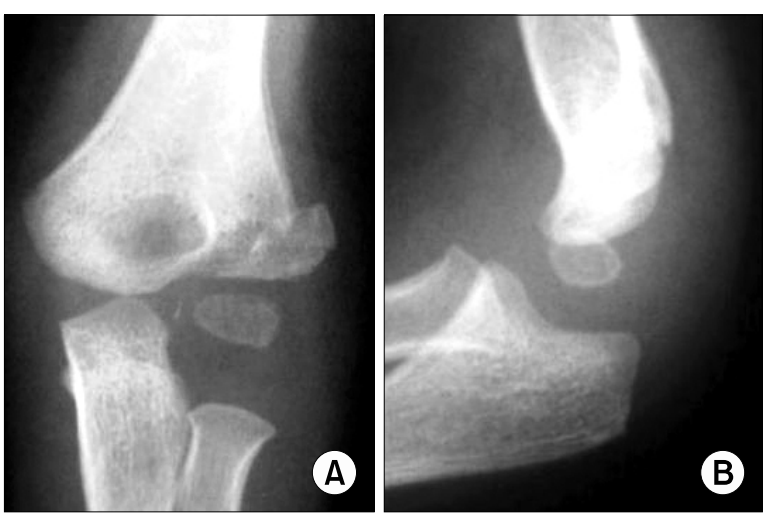

Fig. 1. A 3-year-old child with a lateral condyle fracture of the humerus. Antero-posterior $(\mathrm{A})$ \& lateral $(\mathrm{B})$ radiographs showing a displaced lateral condylar fragment with some callus at 5 weeks after injury. terior cortices were used to measure the distance on lateral radiographs (Fig. 1). The greatest displacement measured was recorded as the amount of fragment displacement. Radiographs at follow up were analyzed for complications including AVN, overgrowth, nonunion, and deformity. One staff surgeon (S.K.S) performed the operations. The lateral approach was used, and the fracture sites were approached directly by minimally and carefully splitting the brachioradialis muscle under the control of an image intensifier to avoid stripping the extensor from the posterior aspect of the lateral condylar fragment. Fractures were reduced anatomically by open reduction and fixed with 2 smooth Kirshner's wires followed by long arm cast immobilization for 4 weeks (Fig. 2). The 2 smooth Kirshner's wires were removed at 4 or 5 weeks postoperatively and elbow active range of motion exercises were started. At final follow ups, ranges of motion and carrying angles were measured. Elbows were also examined for tenderness, lateral prominence or neurologic signs. Patients were asked to rate pain and activity, i.e., limitation of activity in any way at the elbow. Patients were rated using the scoring system described by Dhillon et al. (Table 1).
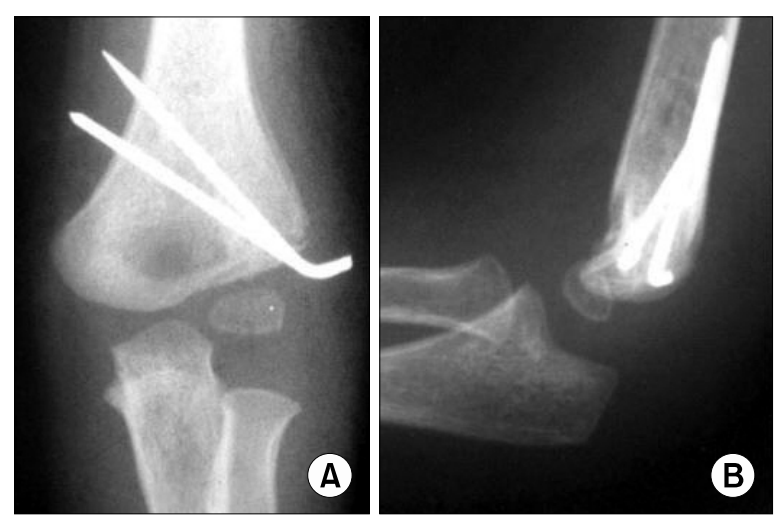

Fig. 2. Postoperative antero-posterior $(A)$ \& lateral $(B)$ radiographs of the same case. The fracture was reduced anatomically with open reduction and fixed with 2 smooth Kirshner's wires. 
Table 1. Details of Patients with a Late Presented Displaced Lateral Condylar Fracture of the Humerus

\begin{tabular}{|c|c|c|c|c|c|c|c|c|c|}
\hline \multirow{2}{*}{ Pt. } & \multirow{2}{*}{$\begin{array}{c}\text { Initial } \\
\text { treatment }\end{array}$} & \multirow{2}{*}{$\begin{array}{l}\text { Injury age } \\
\text { (year) }\end{array}$} & \multirow{2}{*}{$\begin{array}{l}\text { Time to late } \\
\text { ORIF (day) }\end{array}$} & \multirow{2}{*}{$\begin{array}{l}\text { Ini Disp } \\
\text { (mm) }\end{array}$} & \multirow{2}{*}{$\begin{array}{l}\text { Present } \\
\text { Disp (mm) }\end{array}$} & \multirow{2}{*}{$\begin{array}{c}\text { Postop } \\
\text { Disp (mm) }\end{array}$} & \multicolumn{3}{|c|}{ Physical examination } \\
\hline & & & & & & & $\mathrm{Ca}$ & Lat & ROM (degree) \\
\hline 1 & LAC & 2.8 & 35 & 1.5 & 3 & $<1$ & 12 & $S L$ & $0-140$ \\
\hline 2 & LAC & 2.9 & 23 & 1.8 & 4 & $<1$ & 8 & $\mathrm{SL}$ & $0-145$ \\
\hline 3 & LAC & 1.8 & 23 & 1.5 & 3 & $<1$ & 5 & NO & $0-140$ \\
\hline 4 & LAC & 4.4 & 21 & 1.5 & 3 & $<1$ & 10 & NO & $0-150$ \\
\hline 5 & LAC & 1.1 & 22 & 1 & 4 & $<1$ & 5 & NO & $0-140$ \\
\hline 6 & LAC & 4.4 & 21 & 1.5 & 4 & 1 & 5 & NO & $0-140$ \\
\hline 7 & LAC & 5.2 & 24 & 2.2 & 3 & $<1$ & 8 & NO & $-5-150$ \\
\hline 8 & LAC & 5.0 & 29 & 1 & 3 & $<1$ & 8 & SL & $0-140$ \\
\hline \multirow{3}{*}{ Pt. } & & & \multicolumn{7}{|c|}{ Rating by Dhillon criteria } \\
\hline & \multirow{2}{*}{\multicolumn{2}{|c|}{ Radiograph }} & Pain & \multicolumn{2}{|c|}{ Carrying angle } & $\mathrm{ROM}$ & \multicolumn{3}{|c|}{ Result } \\
\hline & & & \multicolumn{4}{|c|}{ (points) } & Functional & & Overall \\
\hline 1 & \multicolumn{2}{|c|}{$\begin{array}{l}\text { SL lateral OG } \\
\text { SL fishtail }\end{array}$} & 3 & \multicolumn{2}{|c|}{2} & 3 & 6 (Excellent) & & 8 (Good) \\
\hline 2 & \multicolumn{2}{|c|}{ SL lateral OG } & 3 & \multicolumn{2}{|c|}{3} & 3 & 6 (Excellent) & & 9 (Excellent) \\
\hline 3 & & & 3 & \multicolumn{2}{|c|}{3} & 3 & 6 (Excellent) & & 9 (Excellent) \\
\hline 4 & & & 3 & \multicolumn{2}{|c|}{3} & 3 & 6 (Excellent) & & 9 (Excellent) \\
\hline 5 & & & 3 & \multicolumn{2}{|c|}{3} & 3 & 6 (Excellent) & & 9 (Excellent) \\
\hline 6 & \multirow{2}{*}{\multicolumn{2}{|c|}{ SL fishtail }} & 3 & \multicolumn{2}{|c|}{3} & 3 & 6 (Excellent) & & 9 (Excellent) \\
\hline 7 & & & 3 & 3 & & 3 & 6 (Excellent) & & 9 (Excellent) \\
\hline 8 & & & 2 & 3 & & 3 & 5 (Good) & & 8 (Good) \\
\hline
\end{tabular}

LAC: Long arm cast, Disp: Displacement, Ini: Initial, Ca: Carrying angle, Lat: Lateral prominence, ROM: Range of motion, SL: Slight, OG: Overgrowth.

\section{RESULTS}

All eight children who were available for follow up for more than 2 years postoperatively achieved union. No child developed AVN of experienced nonunion. All cases were initially treated with a long arm cast. No regular follow up was performed during the first three weeks in 3 cases, and further displacement was missed due to a poor quality radiogram through casts in 5 cases. Average age at injury was 3.4 years (range 1.2-5.2), and the average time to ORIF was 24.8 days (range 21-35). Seven fractures were displaced by less than $2 \mathrm{~mm}$ by initial trauma, and one by $2.2 \mathrm{~mm}$ (average 1.5, range $1-2.2$ ). However, on preoperative radiograms, all cases were displaced by more than $3 \mathrm{~mm}$ (average 3.3, range 3-4). All cases could be mobilized without disturbing the soft tissue of the
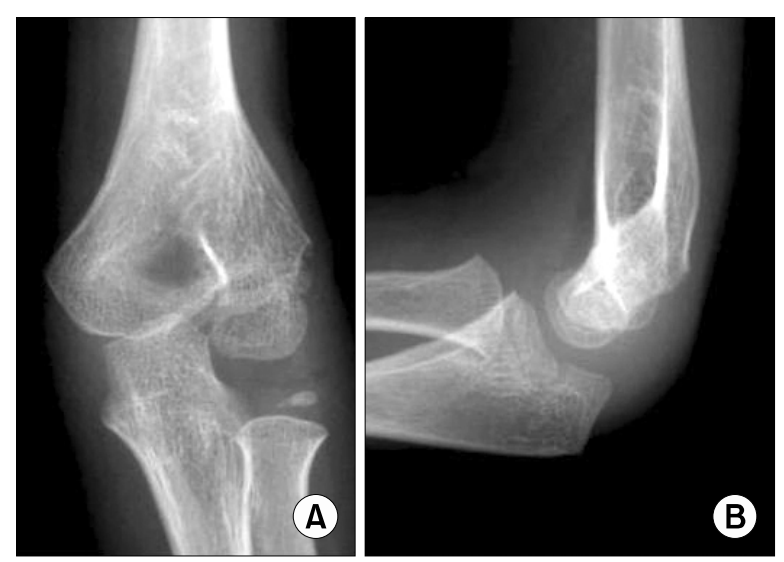

Fig. 3. Three year follow-up antero-posterior (A) \& lateral (B) radiographs showing a small defect at the central portion of the distal articular surface - the so-called "fishtail appearance".

distal fragment and were reduced anatomically to less than $1 \mathrm{~mm}$. There were 2 cases with slight fishtail deformity (Fig. 3) and 2 cases mild loss of 
carrying angle due to overgrowth of lateral condyle fragment (Table 1). Two patients achieved a good result and 6 an excellent result according to the scoring system described by Dhillon et al (Table 1).

\section{DISCUSSION}

LCF accounts for 17-20\% of elbow fractures in children $^{2,13)}$ and most occur between the ages of 2 and 14 years. Nondisplaced or slightly displaced LCFs of the humerus in children may subsequently displace if treated by cast immobilization alone, ${ }^{5-7,12)}$ and nonunion more commonly results from minimally displaced fractures than from severely displaced and rotated fractures, simply because more treatment is administrated in cases of severe fracture ${ }^{6)}$. Our series had minimal displacements of $<2 \mathrm{~mm}$ in anterior-posterior view in seven cases, and $2.2 \mathrm{~mm}$ in one cases at initial injury. Subsequently, displacement occurred after long arm cast treatment alone in all cases. There is unanimity of opinion on the need for open reduction and internal fixation of displaced fracture when seen early, but the management of displaced LCFs presented at $>3$ weeks after injury is controversial. Surgical treatment of late presenting LCF with $<1 \mathrm{~cm}$ of displacement is generally recommended, if care is taken to avoid damage to the delicate vasculature of the lateral condyle fragment ${ }^{3,6-8,10,14,18)}$. Flynn et $\mathrm{al}^{8)}$ recommended late ORIF with bone grafting of a minimal displaced LCF not healed by 12 weeks. However, others have found delayed open reduction unsatisfactory ${ }^{4,9,12,13,17)}$. It is unfortunate that these reports do not clearly mention the timings of surgery inlate cases, although a small number of reports have unambiguously concluded that three weeks is a maximum for open reduction ${ }^{4,8,13)}$. However, Wattenbarger et al reported that 3 late presented $(<7$ weeks) children achieved good functional results after open reduction of a displace fragment and no $\mathrm{AVN}^{18)}$, and Fontanetta et $\mathrm{al}^{9)}$ reported a good result in one case treated with late ORIF (3 weeks), although they recommended that 3 weeks should be consider the latest time that delayed open reduction should be carried out for this injury, as it was felt that 4 weeks is too late for open reduction because of the increased risk of AVN. However, simple observation in 3 late presented cases (4 weeks) for fear of AVN led to serious problems, i.e., nonunion, limitation of motion, valgus deformity, and consequent pain at long term follow up ${ }^{9}$. Jakob also reported one delayed case (7 weeks) that achieved a good result after late ORIF and two delayed cases (3 weeks) with poor results in a group 2 series $^{13)}$. The reason for avoiding late ORIF for delayed patients is the high risk of AVN. Soft tissue become contracted, which makes reduction difficult without stripping soft tissues from the lateral condyle, and this often leads to AVN. Many authors have noted AVN after late open reduction ${ }^{1,4,12,14,16)}$, but more recently, it has been reported that ORIF can be undertaken if care is taken not to strip soft tissues ${ }^{16,17)}$. In a review of late operated cases that resulted in AVN, most of these cases had large delays, i.e., of several months or more, and attempts were made to reduce fragments to their anatomical position by stripping soft tissues.

In our series, fractures were united by callus and fibrous tissue, but they were not firmly fixed and we did not experience difficulty mobilizing fragments. In fact, we were able to mobilize fragments and curettage fracture gaps using the direct approach under the control of image intensifier without stripping soft tissue on the posterior portion of fragments. We consider that delays of greater than 3 weeks still allow anatomic reduction without damaging fragment soft tissue. Although, we are not in a position to say that this small series definitely proves the case, judging from our eight 
patients and other reports, we consider that the delay can be extended to five weeks given a meticulous surgical technique and the avoidance of soft tissue damage ${ }^{13,18)}$.

\section{CONCLUSION}

The authors consider that the amount of delay importantly affects prognosis is cases of late presenting LCF, but that surgical technique involving the preservation of soft tissue warrants equal consideration. Thus, the authors believe that late presented (presented between 3 to 5 weeks) and displaced (less than $4 \mathrm{~mm}$ ) LCFs can be treated successfully by anatomic reduction and internal fixation using the open method without serious complications.

\section{REFERENCES}

1. Badelon $\mathbf{O}$, Bensahel $\mathbf{H}$, Mazda K, Vie P: Lateral humeral condylar fracture in children : a report of 47 cases. J Pediatr Orthop, 8: 31-34, 1988.

2. Bast SC, Hoffer MM, Aval S: Nonoperative treatment for minimally and nondisplaced lateral condyle fractures in children. J Pediatr Orthop, 18: 448-450, 1998.

3. De Boeck H: Surgery for nonunion of the lateral humeral condyle in children. 6 cases followed for 1-9 years. Acta Orthop Scand, 66: 401-402, 1995

4. Dhillon KS, Sengupta S, Singh BJ: Dealyed management of fracture of the lateral humeral condyle in children. Acta Orthop Scand, 59: 419-424, 1988

5. Finnbogason T, Karlsson G, Lindberg L, Mortensson W: Nondisplaced and minimally displaced fractures of the lateral humeral condyle in children: a prospective radiographic investigation of fracture stability. J Pediatr Orthop, 15: 422-425, 1995.

6. Flynn JC: Nonunion of slightly displaced fractures of the lateral humeral condyle in children: an update. J Pediatr Orthop, 9: 691-696, 1989.
7. Flynn JC, Richards JF Jr: Non-union of minimally displaced fractures of the lateral condyle of humerus in children. J Bone Joint Surg Am, 53: 1096-1101, 1971.

8. Flynn JC, Richards JF Jr, Saltzman RI, et al: Prevention and treatment of non union of slightly displaced fractures of the lateral humeral condyle in children. An end-result study. J Bone Joint Surg Am, 57: 1087-1092, 1975.

9. Fontanetta P, Mackenzie DA, Rosman M: Missed, maluniting, and malunited fractures of the lateral humeral condyle in children. J Trauma, 18: 329-335, 1978.

10. Foster DE, Sullivan JA, Gross RH: Lateral humeral condylar fractures in children. J Pediatr Orthop, 5: 16-22, 1985.

11. Gaur SC, Varma AN, Swarup A: A new surgical technique for old ununited lateral condyle fracture of the humerus in children. I Trauma, 34: 68-69, 1993.

12. Hardacre JA, Nahigian SH, Froimson AI, Brown JE: Fractures of the lateral condyle of the humerus in children. J Bone Joint Surg Am, 53: 1083-1095, 1971.

13. Jakob R, Fowles JV, Rang M, Kassab MT: Observations concerning fractures of the lateral humeral condyle in children. J Bone Joint Surg Br, 57: 430-436, 1975.

14. Masada K, Kawai H, Kawabata H, Masatomi T, Tsuyuguchi Y, Yamamoto K: Osteosynthesis for old, established nonunion of the lateral condyle of the humerus. J Bone Joint Surg Am, 72: 32-40, 1990.

15. Roye DP Jr, Bini SA, Infosino A: Late surgical treatment of lateral condyle fractures in children. J Pediatr Orthop, 11: 195-199, 1991

16. Shimada K, Masada K, Tada K, Yamamoto T: Osteosynthesis for the treatment of nonunion of the lateral condyle of humerus in children. J Bone Joint Surg Am, 79: 234-240, 1997.

17. Smiths FM: An eight-four tear follow-up on a patient with ununited fracture of the lateral condyle of the humerus. A case report. J Bone Joint Surg, 55: 378-380, 1973.

18. Wattenbarger JM, Gerardi J, Johnston CE: Late open reduction internal fixation of lateral condyle fractures. I Pediatr Orthop, 22: 394-398, 2002. 


\section{$=$ 국문초록 $=$}

목적: 3 주 이상 지연 발현된 전위된 소아 상완골 외과 골절에 대해 관혈적 정복 및 내고정술이 가능한지 그리고 최대 언제까지 치료가 지연되어도 골 이식 없이 관혈적 정복 및 내고정이 가능한지를 알아보고자 한다.

대상 및 방법: 3 주 이상 지연 발현되었고 $2.5 \mathrm{~mm}$ 이상 전위된 소아 상완골 외과 골절에 대해 관혈적 정복 및 내고정술을 시행한 8 예를 대상으로 하였다.

결과: 임상적 치료 결과는 우수가 6 예, 양호가 2예였다. 수술 후 불유합이나 무혈성 괴사 같은 심한 합병증은 전 예에서 관찰되지 않았으나 2예에서 경도의 물고기-꼬리 변형과 외과 골편의 과성장으로 인한 경도의 운반각 소실이 있었다.

결론: 지연 발현된 소아 상완골 외과 골절에서 무혈성 괴사의 위험성 없이 관혈적 정복을 시행할 수 있는 허용 기간으로 3 주는 너무 짧다고 생각되며, 최대 5 주 혹은 그이상도 수술적 치료를 통하여 양호한 결과를 얻을 수 있을 것으로 생각된다.

색인 단어: 지연된 관혈적 정복, 상완골 외과 골절, 소아 